Plans for the quinquennium 1951-55 include an increase in the allocation for the development of museum services from $£ 30,000$ to $£ 40,000$, in part with the object of strengthening the administration of the Museums Association itself. For the Councils of Social Service of England, Scotland, Northern Ireland, and Wales and Monmouthshire, $£ 27,750$

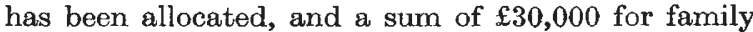
case-work by the Family Welfare Association and Family Service Units. With allocations of $£ 45,000$ for music and drama and $£ 5,000$ for the visual arts, the total allocation for the new quinquennium is $£ 147,750$, and there is thus some three-quarters of the Trust's funds for the period still available for allocation.

\section{RECURRENT LONG LEAVE FOR UNIVERSITY TEACHERS}

$\mathrm{T}$

HE seventeenth issue of Communication contains the report of the International Association of University Professors and Lecturers on recurrent long leave. By this is meant the recurrence of substantial periods of leave over and above ordinary annual vacations; the most usual arrangement is that every seventh year is recognized as a year of leave of absence from the plaze of normal occupation. It is well known that some universities have such schemes, while others have not. It has not been generally known precisely which universities fell into which category, nor has there been any clear knowledge as to what variations of the typical schene there might be in universities which operate recurrent long leave schemes. A suitable questionnaire was therefore sent to fifty-eight countries where universities exist. Thirty-seven of these have replied, fifteen of them reporting that they have no regular system for long leave. These are Sweden, Finland, France, Switzerland, Belgium, the Netherlands, Austria, Hungary, Czechoslovakia, Germany, Eire, Italy, Mexico, Chile and Bolivia. This does not mean a notable lack of interest on the part of either staff or authorities. Eire ('Trinity College, Dublin), for example, though having no system, does occasionally give long leave when a member of staff is invited to spend some time in another university. In the University of Brno, a professor or his associate is occasionally granted leave with full salary for study for a period of, say, three months to a year. Similarly, the University of Chile has provision for granting leave for, say, six months on full salary for study purposes - each case being considered on its merits. In Finland, the University of Abo grants leave of absence with full salary and superannuation, the recipient usually having the obligation of paying a deputy.

The other twenty-two countries have recognized systems for recurrent long leave, although in some of the countries, like Canada, Great Britain and the United States, by no means all the universities have any definitely established systems; it is in the British Commonwealth of Nations and in the United States that the practice is most firmly rooted. The list of countries in which some or all of the universities have systems for recurrent long leave is as follows : Australia, Burma, Canada, Ceylon, China, Denmark, Egypt, Greece, Iceland, India, Israel, Lebanon, Malaya (Singapore), Norway, New Zealand, Philippine Republic, South Africa, Trinidad, Turkey,
United Kingdom, the United States and Yugoslavia. From the data supplied it is clear that there is a widespread desire among the universities of the world that a regular leave system should operate. Many individuals, both members of the teaching staff and administrative authorities, of several universities, have expressed their views strongly in support of the system. The general aim would appear to be a scheme on 'sabbatical' lines in the sense that approximately every seventh year should be available for leave. The majority, however, both of those who give it and of those who take it, prefer that the leave be spent usefully in study or research, while travel and rest are not excluded.

Although on paper some of the schemes appear to be satisfactory, they may not be completely realistic. In the Hebrew University of Jerusalem the scheme would appear to be working well, a high percentage of members of staff taking advantage of it. In Egypt and Ceylon advantage is taken of the opportunities offered. The New Zealand schemes which have been quite recently financed by a special grant from the Department of Education are likely to prove very attractive. On the other hand, there would appear to be a good deal of imperfection in the machinery of some of the others which considerably reduces their effectiveness.

In most cases full pay is continued during leave, although in some there is a downward adjustment. On the other hand, Egypt and Lincoln (New Zealand) add a cost-of-living bonus. Generally, the staffstrength of a department provides for leave to a teacher without the need for a substitute; but where a substitute is required, in some cases the institution provides for the payment and in others it is the individual who pays in part or in full. One of the major expenses attending leave is that of travel. Long-distance passages are covered or partially met by a grant-in-aid by about half the universities who have replied; in other cases the whole cost falls on the member. In the latter event only teachers in universities where the salaries and other emoluments are relatively good can avail themselves of the leave or attempt to undertake longdistance travel. Another difficulty which arises in some cases is that, if a man is to take his wife and family with him, it naturally adds a good deal of expenditure, whereas if he leaves them behind he has two establishments to finance. Interesting examples in this connexion are Ceylon, Egypt, Western Australia and Yugoslavia. In Ceylon a travelling allowance is made for a wife, in Egypt for both wife and children, in Western Australia a larger house allowance is made in the case of a married man on leave, and in Yugoslavia the needs of the family are arranged for by paying to them the member's salary, the member on leave receiving instead his living and travelling expenses.

In reviewing the replies to the questionnaire, the Association recommends that a system of long leave at recurrent intervals should be established in all university institutions of the world. Where such a system cannot be established, all facilities for ad hoc refresher or study leave should be granted. Such leave should be with full pay and superannuation and adequate travelling allowances. If it should be necessary to pay for a substitute, funds should be provided by the institution for this purpose. The leave should be devoted to research, travel, rest or any other purpose to which the academic authorities could take no reasonable objection. 